\title{
REGULATING THE AUSTRALIAN LEGAL PROFESSION THE LAW SOCIETIES AND BAR ASSOCIATIONS ${ }^{1}$
}

\author{
Don Fleming ${ }^{2}$
}

\begin{abstract}
Abstrak
This article does figure on the legislation progress of Australian legal profession. The change itself has been started during past 20 years under external force of law society. After in decade of 1990 progress that not significantly changes result in effect by not sufficient support from all goverments. But in the last progress has come from national government to liberate the legal services market from the inconsistencies of the previous system of State and Territory based regulation. It's aimed to pull of Australian economy perspective by efficiency and national coherent market for legal services. On the author thought the recent change in the law reform was triggered by legal profession (Law Council of Australia) as major contributor that be encouraged by larger commercial firms.
\end{abstract}

Kata kunci: hukum acara, praktek hukum, Australia, pengaturan, komunitas hukum

\section{Introduction}

Australia occupies an area of approximately $7.7 \mathrm{~m}$ square kilometres. Roughly two thirds of its landmass is arid or semi-arid. ${ }^{3}$ The total population of Australia is now $21.5 \mathrm{~m}$ people. Aboriginal and Torres Strait Islander peoples comprise an estimated 2.5 per cent of the population. ${ }^{4}$ Approximately 95 per cent of the population is Anglo-Celtic or European in origin. ${ }^{5}$ Between two and three per cent of Australians have Asian ancestry,

${ }^{1}$ Paper presented via video link to a symposium hosted by the Fakultus Hukum, Universitas Indonesia, 19th November 2008.

${ }^{2}$ Writer is a Associate Dean (Research), Faculty of Law, University of Canberra.

${ }^{3}$ SBS (2001), p. 41.

${ }^{4}$ ABS (2008).

${ }^{5}$ SBS, above n 1 
China and India being the principal ancestor societies. ${ }^{6}$ In the 2006 national census almost 64 per cent of Australians reported an affiliation with Christianity. ${ }^{7}$ Six per cent had other religious beliefs including 1.7 per cent or 340,000 Australians affiliated to Islam. ${ }^{8}$

The object of this paper is to provide a short introduction to the role of the law societies and bar associations in the regulation of the legal profession in Australia. The paper is organized into three parts. The first part of the paper provides snapshots of Australian government and law and the legal profession.

\section{Australian Government and Law}

Australia has a monarchical federal parliamentary system of government. Legislative power is divided between a national parliament and the parliaments of six constitutionally autonomous States. ${ }^{9}$ There are also two self-governing Territories ultimately subject to the national parliament. Executive power rests formally in the Crown as head of state. In practice and by convention executive power is exercised following the UK cabinet model by ministers chosen by the parliamentary leader of the majority political party. Government policies and programs are administered by central and State and Territory government systems of public administration. Local government plays a comparatively small role.

Australia belongs to the common law world. The courts are organized federally. The High Court of Australia is the constitutional court and the ultimate court of appeal in other matters. Two other Federal superior courts, a magistrates' court and various tribunals exercise jurisdiction in national law. Comparable systems of courts exist in each State and Territory exercising jurisdiction in local law and, in some circumstances, Federal jurisdiction. Although Australian judges are state officials appointed by governments the presence of the doctrine of the separation of powers, conventions of governance, an autonomous legal profession and its assertive

${ }^{6} \mathrm{ABS}(2007(\mathrm{~b}))$.

${ }^{7}$ Almost 30 per cent of census respondents or $5.9 \mathrm{~m}$ people reported having no religion or did not state a religious affiliation.

${ }^{8}$ ABS (2007(a)).

${ }^{9}$ See Wikipedia contributors (2008) for an overview of the Australian political system. 
cultures combine to support a strong and vibrant tradition of judicial independence. Judicial independence is a feature of Australian democracy and is particularly important today in a society that is yet to: enact a national bill of rights.

\section{A Snapshot of The Legal Profession}

The most recent Australian Bureau of Statistics (ABS) survey of the legal services industry was conducted in 2001/02. The ABS survey identified 36,124 legal practitioners. The majority of these lawyers were in private practice.

The occupational divide between barristers and solicitors is still important in Australia even though the distinction has lost its significance for admission purposes. Barrister advocates still dominate legal work inside courts; solicitors are still largely engaged in other legal work. Different conditions attach to practicing certificates issued to barristers and solicitors.

In 2001/02 almost 30,000 solicitors were employed in private firms, approximately 50 per cent as partners - across all firms. Approximately 50 per cent worked as employed solicitors, with almost equal numbers of men and women.

There were 7,566 solicitors' practices. The majority of practices were sole practices, 69 per cent having one principal or partner. Another 18 per cent had only two principals or partners. Only 1.2 per cent of all solicitors' practices had 10 or more partners. In other words, the industry continues to be dominated by small firms. Almost 80 per cent of all solicitors' practices were located in the eight capital cities.

Women accounted for almost 34 per cent of all solicitors - partners and employed solicitors - in law firms. In contrast only 20.5 per cent of all partners and principals were women. Women partners were most strongly evident in sole practices ( 24 per cent), and practices with two working partners (28 per cent). In large firms with more than 10 partners only approximately 17 per cent of all partners were women.

In 2001/02 the major areas of solicitors' work were:

a) Commercial legal services (36.7 per cent);

b) Property work (28.6 per cent);

c) Personal injury work (10.6 per cent);

d) Family law (10.8 per cent);

e) Other legal services ( 9.3 per cent);

In 2001/02 there were 3,670 barristers in practice, of whom 384 were QCs or Senior Counsel. The majority of barristers were located in NSW 
(43.9 per cent) and Victoria (32.8 per cent). The majority of barristers were men, women comprising only 24.4 per cent of the total population of barristers.

\section{The Law Societies and Bar Associations}

There is no single bar association in Australia. The organization of the legal profession reflects the federal system of government. Independent and autonomous professional organizations exist in the eight States and Territories. The organization of the legal profession reflects the occupational divide. Solicitors belong to the law societies; barristers belong to the bar associations.

Some of the eight State and Territory law societies are incorporated. ${ }^{10}$ Others are unincorporated associations. "Since the National Competition Policy reforms of the late 1990s membership of the law societies has been voluntary. ${ }^{12}$ The majority of practicing solicitors belong to the law societies. In July 2008, for instance, the Law Society of NSW reported membership of almost 94 per cent of all practicing solicitors. ${ }^{13}$

As professional associations the law societies have two principal objects. One of the objects is to too consider, originate and promote reform and improvements in the law. The other principal object is to represent the interests of the legal profession, including:

a) representing generally the views of its members;

b) preserving and maintaining its integrity and status;

c) suppressing dishonourable professional conduct or practices;

d) providing amicable settlement or adjustment of professional disputes;

e) engaging with all matters affecting the professional interests of solicitors; ${ }^{14}$

${ }^{10}$ e.g, The Law Society of New South Wales, (see <http://www.lawsociety.com.au/ page. asp?partid $=66>$, accessed 5 November 2008.

11 E.g., the Law Institute of Victoria, (see http://www.liv.asn.au/ (accessed 5 November 2008)).

${ }^{12}$ Solicitors and barristers are required to pay fees for annual practising certificates but payment of annual fees for law society or bar association membership is optional.

${ }^{13}$ The Law Society of New South Wales (2008), p. 8. 
Responsibility for governance rests with councils comprising 10-20 law society members elected for two or three year terms. Much of the work involved in implementing the law societies' objectives is performed by council sub-committees. In NSW, for instance, 24 such committees advise and assist the council on professional and law reform issues such as costs, environmental planning and development, human rights, injury compensation, medico-legal issues, ethics and professional conduct. ${ }^{15}$ Membership is by invitation and voluntary and can include non-lawyers. Since the early 20 th century the expertise mobilized through the committee system has enabled the law societies to contribute to a wide-range of proposals to reform the law. Justice Ministers and officials and the courts expect such contributions and demand for law society involvement is growing. In 2007/08, for instance, The Law Society of NSW responded to over 170 law reform proposals, not counting proposals related to regulating the legal profession. ${ }^{16}$ The work of the law societies is supported by administrative secretariats ranging in size from about 10 to $>150$ staff, depending on membership numbers and income.

As indicated above only about 10 per cent of lawyers practise as barristers. Consequently the State and Territory bar associations are correspondingly smaller in size. Organizationally there are many similarities between the bar associations and the law societies. ${ }^{17}$ The major difference is that the bar associations represent and emphasize the role of barristers and an independent bar in ensuring justice under the rule of law. ${ }^{18}$

The Law Council of Australia represents the legal profession nationally. The Law Council differs from the law societies and bar associations in two important respects. It has no direct regulatory role. Instead the Law Council is a peak body promoting the interests of Australian lawyers on national and international issues and pursuing wider objectives including:

${ }^{14}$ e.g., Memorandum and Articles of Association of the Law Society of New South Wales, cl. 3 (1) \&(2).

15 Other committees include arbitration liaison, business law, corporate lawyers, criminal law, dispute resolution, elder law and succession, employment law, fidelity fund management and legal technology. See The Law Society of New South Wales (2008), pp. 6-7.

${ }^{16}$ The Law Society of New South Wales (2008), pp. 16-17

${ }^{17}$ e.g., "About the New South Wales Bar Association" < http://www.nswbar.asn.au/ about.php>, accessed 6 November 2008 .

${ }^{18}$ e.g., Victorian Bar Council (1990), pp. 29-30. 
a) promoting and defending the rule of law in the public interest;

b) representing the law societies and bar associations at a Federal level in all matters;

c) involving uniformity of State Laws, reform of Federal Law and legal practice in Federal Courts and in dealings with the national Government and its Ministers;

d) developing and promoting Federally educational, regulatory and organisational initiatives to improve the practise of law;

e) promoting the administration of justice and the development and improvement of law throughout Australia;

f) upholding the honour of the profession of the law;

g) encouraging cordial intercourse among the members of the legal profession;

h) advancing the science of jurisprudence; ${ }^{19}$

Nor are individual lawyers members of the Law Council. Instead its membership is constituted by legal professional organizations, in practice, to date the State and Territory law societies and bar associations. Individual lawyers are eligible for membership of the Law Council Business Law, Family Law, Federal Litigation, Legal Practice and International Law sections. ${ }^{20}$ Seven standing committees of lawyers provide the Law Council with specialist advice on specific legal issues and contribute to law reform and legal policy development and debates.

\section{The Regulation of The Legal Profession}

For much of the $20 \mathrm{C}$ the Australian legal professions was "very successful" at resisting change. From the 1960s there was growing pressure for reform, from consumer organisations, legal academics and progressive lawyers and labour economists. However, "in the absence of any popular passion or movements for restructuring legal practice, few governments ... ultimately thought it prudent to challenge the legal profession's vested interests".

${ }^{19}$ Law Council of Australia (2003), p. 8.

${ }^{20} \mathrm{See}<\mathrm{http}: / /$ www.lawcouncil.asn.au/sections.html>, accessed 6 November 2008. Only lawyers who belong to a constituent legal professional organisation such as a State or Territory law society or bar association are eligible to join a Law Council section. 
In its four reports over 1982-84 the NSW Law Reform Commission proposed wide- ranging changes to the regulation and structure of the legal profession. A combination of opposition from lawyers, and the government's conflicts with doctors over private practice in public hospitals, legislation was not enacted until 1987, and, in the end, did not "represent much of a threat to professional autonomy".

Concerns about access to justice were also relevant. By the mid-1980s there were growing concerns about the cost of access to justice and legal services. This generated political support, and also popular support. In 1987 the Senate Legal and Constitutional Affairs Committee had announced a wide ranging into the costs of legal services. Over 1988-92 the Senate Committee looked at a wide range of issues and made two reports, containing a number of recommendations with respect to the legal profession. There were comparable developments in the States, and a number of reports into the cost of legal services, and the role of lawyers.

The emphasis on improving the efficiency of the economy and its international competitiveness which followed the 1983 decision to pursue a national micro-economic reform changes had created "a political climate favourable to regulatory reform", including "wider recognition of the need to eliminate or avoid unnecessary impediments, especially in the form of further government regulation and restrictive work". Over 1983-85 the Trade Practices Commission (TPC) conducted a study of the operation, efficiency and consumer benefits of industry self- regulation, including the legal profession. The report of the study found "considerable scope for an expansion of business self-regulatory activity". The TPC saw a number of industries as amenable to further development of such approaches, but not expressly the legal profession.

In 1988 the TPC announced an inquiry into the exemption of professional occupations including law from the Trade Practices Act 1974 (Cth) (TPA). The inquiry was to investigate whether the exemption of the professions from the TPA served the public interest, or the professions themselves, and was to focus on conduct and structural constraints inhibiting competition in professional markets. In particular, measures operating in professional markets such as fee setting, restrictions on advertising and promotion and ethical and disciplinary standards intended to influence the conduct of professional work, and structural restraints, such as restrictions on entry, including licensing, certification, and qualification and competency standards, functional separation and controls on enterprise ownership and organisation.

In summary at the end of the 1980 s the regulation of the legal profession in Australia was a classic example of a professional labour 
market. Reservations existed on work, titles, entry and rights of appearance in the courts, and a combination of self-regulatory arrangements -passively endorsed by governments - and co-regulatory arrangements - actively endorsed by governments - regulated the structure of the legal services market, and the conduct of the work of solicitors and barristers. The result was that the legal profession and its members dominated markets for legal services.

This was a market that was fragmented, both in regulatory arrangements and in operation. The system of jurisdiction-based regulation limited lawyers to working in one State or Territory, unless they obtained separate admission and licensing in another State or Territory. The regulatory arrangements also impeded the development of legal practices that worked nationally, those that existed were in-effect a federation of State or Territorybased firms.

\section{The Winds of Change}

In 1990 one of the first steps was taken towards establishing a national approach to the regulation of the legal professions. The Standing Committee of Attorneys-General (SCAG) began to work with legal professional bodies to remove impediments to reciprocal admission to legal practise, harmonisation of relevant educational and practical training requirements and the adoption of a scheme that allowed reciprocal admissions, without the need to attend court.

These goals were partly achieved through the Mutual Recognition Act 1992 (Cth) that provides that persons registered for an occupation in one State, is entitled to be registered for the occupation in another State. Section 18 (3) provides that "an exampled of such an occupation is that of a legal practitioner, which involves both the admission as a legal practitioner by a court and the issue of a practising certificate by another body". The Australian Government also established the International Legal Services Advisory Council to help improve Australia's performance in international market for legal and related services.

The period over 1990-94 was one which saw the engines of reform of the legal profession really start up, and we will briefly consider the major influences at the national level. At the same time there were also reforms underway in the States, but our focus is on the national process.

Australian governments had become concerned at the slow pace of the reforms required to facilitate the operation of the economy as a single integrated market, particularly with respect to the domestic sector, include professional services markets. Concerns also existed about the limited 
operation of the TPA in domestic markets, "with coverage depending on ownership or corporate form rather than considerations of community welfare".

In 1992 the Australian Government commissioned an independent inquiry (known as the Hilmer Committee) to design a competition policy framework. The Hilmer Committee, which reported in August 1993, took "a broad approach", identifying both the need to strengthen pro-competitive regulation, and remove anti-competitive legislative interventions.

The emphasis of the Hilmer Report was on structural reform, particularly with respect to legislatively mandated constraints applying to public utility monopolies and statutory marketing schemes. The report also addressed the anti-competitive effects of occupational licensing, such as operated in the legal profession. The Committee recommended that an effective national competition policy required four key measures:

a) establishment of a national competition commission;

b) extension of the TPA, Part IV, market conduct rules to all businesses, including the professions;

c) government action to ensure that regulatory provisions in Commonwealth, State and Territory laws did not restrict competition, unless the restriction was demonstrably in the public interest;

d) review of all existing laws imposing a significant restriction on, and anti-competitive provisions repealed;

\section{These Plans Clearly Effected The Legal Profession.}

In October 1993 the TPC released a draft report of its study of the regulation of the legal professions. The report found that existing regulatory arrangements far exceeded those applying to other businesses and professions, and did not produce "demonstrated public benefits which more than offset their anti-competitive effects". The TPC saw four issues as fundamental to reform of the legal profession:

a) application of the competition principles and policies advocated by the Hilmer Committee;

b) application of the TPA market conduct rules to the legal profession and its work greater uniformity in the State and Territory schemes regulating the legal profession;

c) the development of an integrated national market for legal services; 
The draft report also identified specific regulatory arrangements restricting competition, and proposed specific reforms to the operation of legal services markets, including:

a) reform of entry restrictions;

b) support for a fused profession;

c) qualified support for specialist accreditation;

d) freedom of choice in business structures;

e) freedom to inform, advertise and attract business;

f) reform of fee scale regimes;

g) support for a limited form of contingency fee;

h) improved complaints handling and discipline;

i) abolition of QCs;

j) reducing professional indemnity insurance restrictions;

In February 1994 the Council of Australian Governments (COAG) accepted the Hilmer Committee's report, and agreed that its recommendations should apply economy-wide. Governments were asked to consider the practicalities of implementing a national competition policy, and an inter-governmental officials' standing committee established, to manage the reform agenda.

The standing committee was asked to develop proposals for reform of the legal profession, based on competition policy principles. This task was delegated to a working group which was to:

a) identify obstacles to achieving a competitive national market for legal services;

b) examine existing regulatory arrangements, to identify constraints removable by mutual recognition arrangements, and those which would survive application of the TPA to the professions and identify priorities;

c) propose a timetable for a national reform process;

The working party was asked to consider relevant material, including the final report of the TPC study of the legal profession, and the report of the Access to Justice Advisory Committee (AJAC), established by the Australian Government in 191993 to consider reforms to the legal services system to improve and enhance access to law.

\section{The initial Response of The Legal Profession}

There was widespread support within the legal profession for the application of competition principles to the legal profession and its work. 
In July 1994 the Law Council responded to the COAG decision to develop proposals for the reform of the legal profession by releasing its Blueprint for the Structure of the Legal Profession. The Blueprint supported the application of competition principles to the legal profession, and removal of structural constraints impeding the emergence of a national market for legal services, consonant with preserving "that vital objective of service to the Australian community and quality of service to their clients". ${ }^{21}$ The Law Council also proposed:
a) development of nationally uniform admission requirements and standards;
b) specialist accreditation;
c) a conduct code;
d) introduction of 'travelling' practising certificates;
e) incorporation options for legal practices;
f) permitting own jurisdiction practice by foreign lawyers;

The Law Council indicated that it was developing reform proposals for standards of client care, trust account and fidelity funding legislation and model disciplinary processes and ensuring the national reach of professional indemnity insurance, and suggested further work was required before allowing multi-disciplinary partnerships.

\section{The Trade Practices Commission Final Report}

In March 1994 the TPC released its final report on the legal profession, repeating the core findings of its draft report. In particular, the TPC final report repeated and emphasized that the legal professions were: "heavily over-regulated" resulting in "adverse effects on the cost and efficiency of legal services and their prices to business and final consumers".

The TPC was not satisfied that the arguments made that the special role of the legal profession in the law and in society meant that there was a wider public interest served by retaining this degree of regulation. The final report also repeated the need to establish an integrated national market for legal services.

\section{The report of the Access to Justice Advisory Committee}

The terms of reference of the Access to Justice Advisory Committee (established as noted above) included: 
a) advising on extending the TPA to the legal profession;

b) measures required to create an integrated national profession, including necessary inter-governmental arrangements;

c) establishment of a mechanism to hear complaints from consumers of legal services in federal jurisdictions;

d) the operation of the Federal Costs Advisory Committee;

e) methods of determining fee scales;

f) rules governing the award of costs;

g) removal of anti-competitive restrictions upon practice by lawyers in federal areas of jurisdiction;

h) the formation of multi-professional practices;

In its May 1994 report AJAC supported the application of national competition policies (including the TPA) to legal services markets. Although noting that the reform process should not only be directed at removing anticompetitive market restrictions, but should also promote citizens' access to justice, and be consistent with the administration of justice, taking into account factors such as lawyers' ethical obligations to the courts and clients, and the public interest in maintaining an independent legal profession.

AJAC believed that competition policy was not the only reason to reform the legal profession. In the existing regulatory arrangements there was a "potential for conflict of interest between the professional organisations, as regulators and as representatives of their members. There was also a need for "measures to be taken actively to protect the interests of consumers", including:

a) facilitating "ready access" by consumers to affordable, needs-based legal services;

b) introduction of "requirements that legal practitioners provide their clients with sufficient information to enable them to make informed judgments about engaging lawyers and taking legal proceedings";

c) a need to ensure greater accountability and transparency and recognition of public interest in the operation of the law societies and bar associations;

d) a need to reform the regulatory role of the legal professional associations. AJAC believed that community attitudes to the role and accountability of the professions had changed;

e) all jurisdictions should move to adopt regulatory models that separated the regulatory and representational functions of the professional organizations; 
AJAC also briefly considered "some issues relating to a national profession". For AJAC the optimal solution was establishment of an independent national authority to regulate the work of the legal profession. This "would create the conditions for a truly national legal profession, with uniform entry and regulatory standards throughout Australia". But it would require intergovernmental co-operation "in a manner that would go beyond anything previously achieved in a cooperative scheme affecting the legal profession", and AJAC did "no more than indicate that this is a possible option that COAG may wish to consider".

\section{The Developments Over 1994-95}

At its August 1994 meeting COAG agreed to implement the competitions policy reforms recommended by the Hilmer Committee, including the major reforms to the electricity, gas, water and road transport industries. In April 1995 governments finally settled the terms of a National Competition Policy, executing three intergovernmental agreements that committed governments to reforms "broadly in line" with the Hilmer Committee recommendations.

The significance for the reform of the legal profession was twofold. The Competition Principles Agreement (CPA) provided:

a) the platform to extend the TPA, Part IV, to include the professions and their work;

b) for a national review of all Commonwealth, State and Territory legislation to identify and "remove all anticompetitive provisions, unless such provisions could be demonstrated to have a net public benefit and the purpose of the restrictive provisions could not be achieved other than by legislation";

In May 1995 the Australian Government responded to the AJAC report. The government prefaced its response by emphasizing support for the COAG decision to develop proposals for the reform of the legal professions, and its continuing commitment to "achieving an effective national legal services market". It accepted in principle the AJAC recommendations with respect to the legal profession, including:

a) uniform admission rules and practising certificates;

b) removing the division between solicitors and barristers, and associated restrictions;

c) improving the flow of information for clients, through advertising, and costs and other information; 
d) access to independent information about lawyers' fees;

e) revision and reform of fee scales;

f) introduction of contingency fees;

g) reform of lawyers' business structures;

h) development of an effective complaints systems;

i) review of the reservations of legal work;

The government expressed concern that whilst there had been "encouraging developments in some States" towards introducing reforms to market conduct and structure along the lines recommended by the AJAC that other jurisdictions had "been slow to introduce the necessary reforms". There was a risk "that, in the absence of progress by COAG, the States and Territories would proceed with their own reforms of the legal profession, establishing new but still separate regulatory regimes that would "increase rather then decrease the obstacles to a genuine market in legal services". Accordingly, prompt joint intergovernmental action was "needed to ensure that regulation of the legal services industry is consistent across jurisdictions".

In July 1996 the COAG officers' working group presented its proposals for reform of the legal profession. In particular, the report recommended:

a) the application of national competition policy should be left to the policy and process agreed in the CPA: the regulation of market conduct by the ACCC, and the legislation review process;

b) regulation of other aspects of lawyers and their work should remain with the States and Territories;

c) the States and Territories should "agree not to intervene to protect what may be anticompetitive practices" in legal services markets, and amongst the legal profession";

d) State and Territory law should also "continue to ensure that market failures are remedied, for example, by establishing rules about disclosure of cost information and disciplinary arrangements, fidelity funds and the handling of clients' money;

e) State law should also continue to preserve the justice system by recognizing practitioners as officers of the Supreme Court in each jurisdiction and by ensuring that ethical rules which make the court system work are upheld";

To achieve national reform the States and Territories were not to be bound to introduce uniform legislation. Governments should agree that 
regulatory intervention in the legal profession should be kept to the minimum necessary to protect the public interest in the administration of justice and consumer protection. Those minimum requirements being:

a) licensing and admission schemes;

b) disciplinary and complaints mechanisms;

c) professional indemnity insurance standards;

d) compulsory fidelity funds and trust accounts requirements;

e) consumer protection from unqualified legal practitioners;

f) fees and costs disclosure and assessment requirements;

g) business structures;

h) ethical conduct rules, where self-regulation provides insufficient safeguards;

The working group also recommended that governments agree to 10 other measures to reform conduct and structure in legal services markets, and noted the "development of a national legal services market requires a coordinated approach to reforms which will remove barriers to interstate and national practice".

The working group proposed that COAG should request SCAG to report on implementation issues. COAG should also request the NCC for further work on the boundaries of legal profession work, mandatory insurance policies and the structure of lawyers' business arrangements.

By 1996 all States and Territories had enacted such legislation which, in effect, applied the restrictive trade practices provisions of the TPA to the legal profession and its work. In NSW, for instance, the relevant legislation was the Competition Policy Reform (New South Wales) Act 1995 (NSW) which applied the provisions of Part IV (the Competition Code) as a law of NSW.

\section{The Experience Over 1996-2000}

In 1996, as far as we know, possibly 1997, COAG referred the issue of implementing reform of the legal profession to SCAG, in accordance with the working group report. COAG may also have asked the NCC to carry out the evaluations suggested in the report, but we do not know this yet either.

In 1996 the process of subjecting all provisions in all legislation in Australia that significantly impeded competition to review began. Progress was patchy. In Victoria, NSW and the NT review of the legal profession legislation were completed by 1999 , and significant reforms implemented. In the other jurisdictions the review process lagged. The review recommended "considering opening up further areas of legal work to competition with non- 
lawyers, monitoring national developments in relation to business structures and retaining the professional indemnity insurance monopoly. ${ }^{22}$

Progress in the wider reform project over 1996-2000 was also patchy, and lacked coordination. In 2000 the Australian Law reform Commission (ALRC) published its report on the federal civil justice system, which recommended inter alia that:

the legal professions revise, evaluate and update its ethical conduct rules to take into account changes in the context of legal practice, notably the shift to a more business oriented and specialist profession, in which litigation was no longer the dominant mode of dispute resolution new practice rules accommodating and encouraging a national legal profession", and reflecting "the diversity in practice in the profession and the changing nature of the organization and control of legal work", including specialization, growing corporate and inhouse practice, multi-disciplinary practices and the competitive and international focus of legal services, should be developed In this period leadership at the national level rested with the Law Council, which continued with its own agenda, developing the model and proposals first presented in the 1994 Blueprint. In 1995 SCAG agreed to Law Council proposals for introduction of a national practising certificate. The essence of the National Travelling Practising Certificate Scheme was that a "lawyer who has a practising certificate issued in one state or territory may carry on legal practice in another state and territory without the need to be formally admitted in that other state or territory under the mutual recognition legislation ... [a] lawyer who exercises rights of practice pursuant to the scheme does not need to take out a practicing certificate in the state or territory in which the lawyer seeks to exercise such rights".

In 1996 the Law Council developed a policy on international legal practice, including draft legislation to accredit foreign qualified lawyers, "to encourage and facilitate the internationalisation of legal services and the legal services sector", and draft model rules of professional conduct. It also published a policy on reservations of legal work, and in 1998 adopted a policy supporting the introduction of multi-disciplinary practices, and agreed to support the development of federal professional standards legislation. The year 2000 was a particularly active year for the Law Council:

a) it established a National Profession Taskforce to consider in detail the regulatory reforms necessary to enable national legal practice. Including common admission standards, adoption of national model professional conduct rules and 
nationally uniform professional indemnity insurance, fidelity cover and trust account and costs disclosure provisions, a nationally consistent approach to business structure options, uniform professional standards schemes and a national register of practicing lawyers;

b) it made a submission to governments on federal professional standards legislation;

c) its National Profession Taskforce published a revised issues paper on multidisciplinary practice, considering in particular issues relating to legal professional privilege and conflict of interest;

d) the National Profession Taskforce began work on revising the 1996 draft Model Rules of Professional conduct, in the light of the ALRC, and other comments and issues that had been pointed out;

By 2000 there were cracks beginning to appear in the wider objectives of National Competition Policy. The review process itself had not gone as planned. Under the CPA the review of all legislation in accordance with NCP was to be completed by 31 December 2000 .

But this did not happen. In the case of the review of the legal profession legislation this was also the case, progress remained patchy. In NSW legislation to enact the recommendations of the 1998 NCP review was yet to be enacted. In South Australia the government was still considering the recommendations of the $2000 \mathrm{NCP}$. In the ACT the government was still considering submissions obtained in response to its 1999 discussion paper. In Queensland the review had not been commenced. Nor had an NCP review been conducted in WA or Tasmania. Some States apparently NSW and Victoria had implemented recommended some of the reforms in the COAG report, whilst the others had not, further consideration of the COAG working group recommendations having been deferred, "pending completion and implementation of NCP reviews".

In November 2000 COAG re-affirmed its commitment to NCP, and agreed to several measures to clarify and fine-tune implementation arrangements for NCP as set out in the Prime Minister's letter of 27 October 2000 to Premiers and Chief Ministers. The deadline for completing the legislative review and reform program was extended to 30 June 2002.

\section{The Model Laws Project}

In 2000 SCAG intervened. There were several reasons. As we have seen implementation of the NCP reforms was delayed and patchy, and, even 
when eventually achieved, would still result in a regulatory system that lacked national consistency. This was of particular concern to the Australian Government. In a speech in 2001, for example, the Attorney-General emphasized the importance of a uniform regulatory framework: to assist the legal profession to adapt and respond to technological change and the needs of clients, and to "remain relevant, flexible and competitive in an increasingly borderless world".

The result of SCAG's intervention was the Model Laws Project (MLP). In effect, the MLP subsumed SCAG's response to the 1996 COAG reference, discussed earlier, and it built on the work that had already been done by the TPC and AJAC, and in the unfolding and unfinished NCP reform process.

The goal of the MLP was to finish the job of reforming the legal profession. The MLP had two principal aims. The first was to respond "to the needs of the growing national market for legal services". The SCAG Officers' Group believed that a national regulatory framework that "enables further growth of national firms and other firms which operate across State and Territory borders [would] also enhance the Australian legal service industry's capacity to compete successfully in international markets". The second aim was to benefit consumers. It was believed that the existing regulatory system had sometimes "resulted in distortions in the market which result in unnecessary costs that ultimately affect the consumer".

To these ends the MLP was intended to achieve: "model laws for a national approach to the regulation of the legal profession and the legal services industry ... through the removal of State and Territory barriers". This was to be achieved: "primarily through means of textual uniformity in legislation and regulations where appropriate and the adoption of nationally consistent standards in other areas ... Common legislative rules will apply even though the administrative framework for the regulation of the profession may vary between jurisdictions". The goal was not "to increase the overall level of regulation of the legal profession, but to make adjustments, where necessary, to different regulatory regimes to promote uniformity", and approach that would require "agreement between jurisdictions on the regulatory "paradigm" to be adopted".

\section{Actioning The Model Laws Project}

At its July 2001 SCAG accepted the MLP principles, and agreed that officials should develop proposals for uniform model laws for the regulation of the legal profession, in particular with respect to the 13 regulatory issues identified as requiring attention. Those issues were: 
a) Reservations of legal work;

b) titles of legal practitioners;

c) Practice, including issuing of practising certificates;

d) How practice rules are made;

e) Professional indemnity insurance;

f) Fidelity cover;

g) Trust accounts;

h) Complaints and discipline;

i) Costs;

j) Costs disclosure;

k) Review of legal costs;

Ministers agreed that SCAG "officers should develop proposals for uniform model laws for the regulation of the legal profession, for consideration", and subsequently discussion papers were prepared on each issue.

The SCAG discussion papers in respect of these 13 issues were circulated to the Law Council, which established its own working groups that operated in parallel with the SCAG officers working group, for comment. In October 2001 the Law Council responded to the Model Laws Project, reminding SCAG of the progress already achieved, and urging ministers to continue the co-operative and co-regulatory approach to reform. It indicated that it preferred retention of a State and Territory based regulatory model, limiting the national role primarily to the setting of standards in areas of lawyers' work essential for national practice. An approach which the Law Council believed had "numerous advantages", including removing barriers to national practice, and building on the record of the intergovernmental cooperative approach.

The Law Council a "starting point" in developing national standards would be to identify the regulatory changes that would be required to "support the national practising certificate concept". The Law Council suggested that the subject areas to be addressed in relation to national practice standards should include those already on its National Profession Taskforce agenda (including the regulatory changes necessary to support national practicing certificates). The Law Council noted that the Taskforce had already made substantial progress on many of these projects. Its response proposed that SCAG and the LAW COUNCIL should continue to co-operate closely in relation to the development of national practice standards, and sought to open a dialogue on the most appropriate model for a national standards setting body.

The next steps occurred at the March 2002 SCAG meeting. SCAG noted that that "considerable progress had been made in some areas". 
Ministers agreed that a national legal profession did not require a nationally uniform scheme of regulation. Instead "a regime of consistent State and Territory regulatory practices" would be sufficient, and ministers agreed to "work towards developing proposals for model provisions to harmonise legal profession laws, as a matter of urgency". SCAG officers were asked to consult with the Law Council, "and report back to Ministers" at the next meeting, "with firm proposals". Thereafter there appears to have been negotiations and discussion between the Officers' Group and the Law Council.

The Officers' Group reported to the July 2002 SCAG meeting. The report favoured retention of State and Territory based regulation, the model proposed in the COAG report, and preferred by the Law Council. In summary, the report's proposals were these, first:

a) there should be a uniform (or substantially uniform) national approach to three regulatory areas: admission and eligibility for legal practice, reservations of work and title and prohibitions on unqualified persons engaging in legal practice;

b) uniform "disclosure obligations should apply in all jurisdictions, to facilitate national practice and ensure adequate consumer protection";

In other areas, such as the review of costs, national uniformity was not necessary, provided that there were some agreed national principles. National protocols should, for instance, "support the operation of complaints and discipline systems", and similar remedies should be available in each jurisdiction. However, "the nature of the institution which performs the functions may vary". Similarly, issues such as "whether Government lawyers have practicing certificates, mandatory continuing legal education and fidelity cover for foreign lawyers"should be matters for individual jurisdictions.

The officers' report also recommended reforms to enhance of legal practice, including:

a) practising certificates to be issued on the basis of admission in any State or Territory;

b) consistent participation by all States in the national practising certificate scheme;

c) uniform restrictions on practice for newly admitted practitioners

d) all jurisdictions to participate in the foreign lawyer registration scheme; 
e) rule making bodies to apply core model practice rules, "with rules to be publicly exposed and subject to disallowance";

The officers' advised that some areas were not yet ready for a national approach, including professional indemnity insurance, an issue on which the Law Council had been working. Although in the future the officers' suggested that "it may be appropriate to consider a national scheme of professional indemnity insurance".

The report also noted some differences with the Law Council, for example, the latter favoured a national fidelity fund - cf. the officers' preference for harmonisation. There were also differences in relation to trust accounts, although in respect of these and other areas of difference the report suggested that textual and substantive solutions might be found through further discussion.

The report proposed formalisation of the relationship between SCAG and the Law Council - to enable "progress on uniformity, implementation and new issues to be scrutinised and supervised with a reporting mechanism back through officers to Ministers". A development which the officers' contended would "ensure the process of national reform is implemented and maintained in a manner which is supportive of the national profession model laws principles", and "incorporate ongoing consultation with other relevant professional bodies, regulatory bodies, the judiciary, consumer groups, academics and other relevant stakeholders.

\section{Implementing The Legislative Reforms}

At this stage SCAG prioritised the development of draft national legislation, in relation to the areas in which substantial agreement had been reached. This was done in further consultation with the Law Council, and other stakeholders, including consumer organisations.

We do not know the exact process that was followed. But in May 2003 SCAG circulated a consultation draft of model regulatory legislation. The "thrust" of the Bill "was to provide for the regulation of the legal profession on a consistent national basis". The draft legislation was a work in progress: "made available for the purposes of consultation as part of this process [which did] not yet reflect a number of drafting and policy recommendations ... [a] number of matters contained in the draft are already the subject of review and should not be regarded as finalised".

Later in 2003 - or early 2004 - SCAG approved the release of model provisions. The model provisions were of three types: Core Uniform (CU): core provisions that were to be adopted in each State and Territory using the same wording as far as practicable: Core Non Uniform (CNU): core 
provisions that were to be adopted in each State and Territory, but the wording of the model provisions need not be adopted: Non Core (NC): States and Territories could choose the extent to which they will adopt these provisions. In summary the major features of the regulatory model in the model legislation were:

a) adoption of nationally uniform standards (across the States and Territories) for law degrees and practical legal training, and Australia-wide recognition;

b) enabling legal practitioners to practise anywhere in Australia with a single practicing certificate (issued in a particular State or Territory);

c) adoption of a common approach to identifying the areas of work reserved to lawyers;

d) a requirement to hold a practising certificate to engage in legal practice in areas of work reserved to lawyers;

e) setting out the use of legal titles (legal practitioner, barrister, solicitor) in uniform terms;

f) enabling legal practitioners to practise in a variety of business structures, including incorporated legal practices and multidisciplinary practices;

g) Uniform rules dealing with trust accounts and fidelity funds;

h) Allowing the practice of foreign law in Australia by foreign registered lawyer's on an open and consistent basis;

i) Nationally consistent requirements for disclosure of information on legal costs to clients;

j) Enabling regulatory bodies to share information and cooperate in investigations, including in relation to complaints and discipline;

In July 2004 governments agreed to introduce all the $\mathrm{CU}$ and $\mathrm{CNU}$ provisions in their respective jurisdictions. A Legal Profession Joint Working Group comprising representatives from all governments and the Law Council was established to maintain uniformity and monitor implementation. In 2006 the ACT enacted to the Legal Profession Act, and similar legislation has been enacted in all other States and Territories.

\section{The New Regulatory Roles of The Law Societies and Bar Associations}

The law societies and the bar associations continue to play a major role in the regulation of the legal profession. This paper explains three aspects of that role under the legislation based on the MLP reforms introduced across 
Australia since 2004: admissions, the professional conduct rules and the complaints and disciplinary process. This is particularly true of the law societies, partly because the majority of private practitioners are solicitors, but mainly because solicitors unlike barristers hold trust funds on behalf of client. In many instances the new legislation involves the law societies in the issue and administration of annual practising certificates and professional indemnity insurance arrangements. All the law societies are empowered to regulate trust accounts, including significant investigatory and protective powers, and administer solicitors' fidelity funds.

\section{Admission to The Legal Profession}

In the common law tradition the power to admit people to the legal profession vested in the superior courts of record. Since the late 19th century the Australian Supreme Courts have exercised this power in conjunction with co-regulatory admission processes involving the law societies and bar associations. In the new regulatory arrangements people seeking admission as lawyers must apply to State and Territory statutory admission boards. $21^{23}$ In most jurisdictions such bodies are known as the Legal Practitioners Admission Board. ${ }^{24}$

The composition of the admission boards varies by jurisdiction. In the ACT membership comprises five lawyers including two barristers. ${ }^{25}$ The admission board in NSW has 11 members: the Attorney-General, four senior judges, two nominees of the universities law deans and four legal practitioners. ${ }^{26}$ In some instances legal practitioner members of the admission boards are appointed as representatives of the law society or the bar association. In other instances legal practitioner members are appointed, not in a representative capacity, but on the basis of their own professional standing although the law society and the bar association are probably consulted by the responsible justice minister or officials in the selection and appointment process.

The admission boards advise the State and Territory Supreme Courts on whether or not an applicant satisfies the criteria for admission. To be Chief Justice.

${ }^{23}$ Typically the admission boards are chaired by the regional Attorney-General or

${ }^{24}$ In the State of Victoria the admissions board in known as the Board of Examiners.

${ }^{25}$ See Legal Profession Act 2006 (ACT), s. 558.

${ }^{26}$ See Legal Profession Act 2004 (NSW), s. 680. 
eligible for admission to the legal profession an applicant must satisfy prescriptive and ascriptive criteria. Generally she or he must hold an approved law degree. ${ }^{27}$ As part of such a degree or otherwise applicants are required to have passed examinations in a group of core professional subjects including criminal law, property law and professional conduct known as the 'Priestly 11 ' ${ }^{28}$ The list of prescribed professional subjects was developed in NSW. The law societies and the bar associations had a major role in this, and they were adopted for the purposes of the MLP reforms.

Applicants must also have completed a period of practical legal training (PLT). PLT in Australia can be completed by articles of clerkship. The majority of law graduates seeking admission complete PLT at institutes or bodies. In some cases these are attached to faculties in other cases they are linked to the legal profession. In either case the law societies and the bar associations play an active role in this, and the institutes are staffed and supported by legal practitioners.

The ascriptive requirement is that applicants are required to satisfy certain personal criteria. Originally these were based in the common law. A person was required to be a fit and proper person. Applicants convicted of criminal offences or dishonesty were unlikely to satisfy these criteria. Now the standards are in statute and still include the fit and proper person requirements but now also address matters such as bankruptcy and tax offences etc. If an admission board considers an applicant has satisfied the requirements for admission it must file a compliance certificate with the Supreme Court, and provide a copy to the law society and bar association. If an applicant has not satisfied the requirements for admission the admission board must state the reasons for its decision to the Supreme Court and provide a copy of the statement to the law society and bar association and the applicant. In exercising its powers an admission board may refer an application, or an issue arising in an application, to the Supreme Court. In all applications the law society and the bar association have standing to object to an application. If the Supreme Court is satisfied that an applicant is eligible for admission, and a fit and proper person to be admitted, it may admit him or her to the legal profession. requirements.

${ }^{27}$ Law degrees from all Australian university law schools satisfy the eligibility

28 Criminal law, Torts, Contract, Property law, Equity, Company law, Administrative law, Constitutional law, Civil procedure. Evidence, Professional conduct, and the maintenance of trust accounts) 
Admission to the legal profession does not entitle a person to engage in legal practice. To do so a legal practitioner is required to obtain an annual practising certificate. In some jurisdictions these are issued by the law society; in other jurisdictions by a co-regulator.

\section{The Professional Conduct Rules}

The State and Territory legislation enacting the MLP reforms empowered the law societies and the bar associations to make rules regulating lawyers' conduct. ${ }^{29}$ Different conduct rules apply to barristers and solicitors. ${ }^{30}$ The content is highly comparable. The differences that exist are attributable to differences in occupational function and activities, e.g., the barristers' rules emphasize conduct in advocacy in the courts. The aspects of lawyers' work covered by the current professional conduct rules are summarized in Figure 1 below.

Figure 1: The subject-matter of the legal profession conduct rules

\begin{tabular}{|c|c|}
\hline Relations with clients & $\begin{array}{l}\text { Duty to client } \\
\text { Agreeing to act for a client } \\
\text { Confidentiality } \\
\text { Acting against a former client } \\
\text { Practitioners employed otherwise than by a practitioner } \\
\text { Termination of Engagement } \\
\text { Ownership of clients' documents - termination of } \\
\text { engagement } \\
\text { Acting for more than one party } \\
\text { Avoiding conflict of interest (where practitioner's own } \\
\text { interest involved) } \\
\text { Receiving a benefit under a will or other instrument } \\
\text { Practitioner and client - borrowing transactions }\end{array}$ \\
\hline
\end{tabular}

${ }^{29}$ e.g., Legal Profession Act 2006 (ACT), ss. 579-83.

${ }^{30}$ e.g., Legal Profession (Solicitors) Rules 2007 (ACT) <http://www.legislation. act.gov.au/s1/200731/default.asp>, and Legal Profession (Barristers) Rules 2008 (ACT), $<$ http://www.legislation.act.gov.au/sl/2008-46/default.asp>, accessed 10 November 2008. 


\begin{tabular}{|l|l|}
\hline Advocacy and Litigation & $\begin{array}{l}\text { Duty to a client } \\
\text { Independence - Avoidance of personal bias } \\
\text { Frankness in court }\end{array}$ \\
& Delinquent or guilty clients \\
& Responsible use of privilege \\
& Integrity of evidence \\
& Communications with opponent \\
& Integrity of hearings \\
& Prosecutor's duties \\
\hline Relations with other & Communications \\
Practitioners & Undertakings \\
& Taking over a matter from another practitioner \\
& Transfer of a practitioner's practice \\
& Communicating with another practitioner's client \\
\hline Relations with third & Contracting for services \\
parties & Undertakings \\
& Communications \\
& Debt collection or mercantile agencies \\
\hline Legal practice & Standard of Conduct \\
& Disclosure Requirements \\
& Conducting another business \\
& Referral fees - Taking unfair advantage of potential \\
clients & - Commissions \\
\hline
\end{tabular}

Source: Law Council of Australia, 2002.

The current conduct rules correspond to the established general principles governing lawyers' conduct. The major differences are in the detail. The barristers' rules, for instance, incorporate changes recommended by the ALRC in its review of the federal civil justice system highlighting barristers' duties towards the efficient and proper administration of justice and preventing abuses of legal procedure. ${ }^{31}$ The law societies and bar associations have adopted other reforms proposed by the ALRC into the new conduct rules. The legal profession conduct rules now have legal effect. A failure to comply with the conduct rules can constitute unsatisfactory professional conduct or professional misconduct. ${ }^{32}$

${ }^{31}$ ALRC (2000), pp.229-34.

${ }^{32}$ e.g., Legal Profession Act 2006 (ACT), s. 585. 
Not all the reforms to the professional conduct rules proposed by the ALRC were adopted. The ALRC would have preferred the new conduct rules to describe more closely "the full array of advisory and representational roles undertaken by lawyers" ${ }^{33}$ Instead the conduct rules remain founded upon an outdated ethical paradigm which largely assumes a homogenous and generalist legal profession and "a civil justice system in which litigation is the dominant mode of dispute resolution". ${ }^{34}$ The ALRC also favoured introduction of a principle-rule-commentary approach as adopted in legal profession conduct rules in New Zealand, the USA and some Canadian jurisdictions. $^{35}$

\section{The Complaints and Disciplinary Process}

Historically the complaints and disciplinary system was dominated by the professional associations. Co-regulatory statutory schemes empowered the law societies to receive and hear complaints against solicitors. The bar associations heard complaints against barristers on a non-statutory or informal basis. Power to discipline lawyers for less serious instances of professional misconduct rested de jure with the law societies and de facto with the bar associations. More serious cases of misconduct were prosecuted by the professional associations in the State and Territory Supreme Courts. ${ }^{36}$ The high degree of self-regulation allowed the legal profession was said to be unique amongst professional occupations in Australia. ${ }^{37}$

In the 1970s and 1980s pressure grew to reform the complaints and disciplinary process. In some but not all jurisdictions the control of the professional associations was reduced. By, for instance, including nonlawyers in decision-making and modifying disciplinary processes to improve transparency, independence and accountability. These reforms had a mixed reception from the legal profession which still retained substantial control of the complaints and disciplinary process.

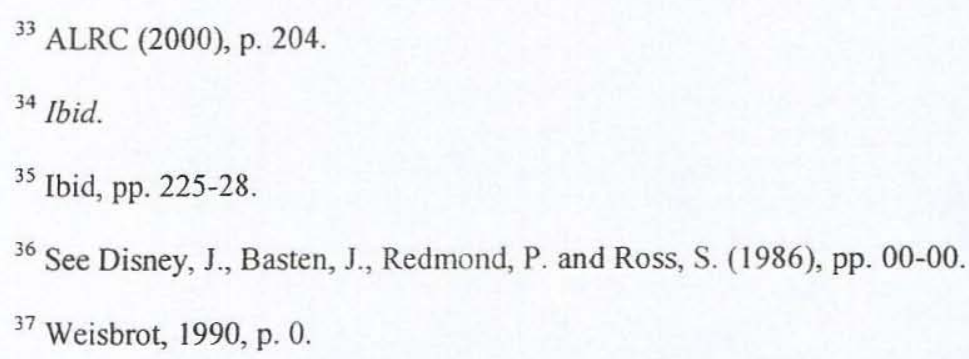


In most jurisdictions the legislation enacting MLP reforms accords the law societies and bar associations a major role in dealing with complaints against lawyers. The new institutional framework is not nationally uniform. In the State of New South Wales for example initially complaints are made to an Office of the Legal Services Commissioner (OLSC) which is a statutory body independent of the legal profession empowered to receive complaints about lawyers. For procedural and disciplinary purposes complaints are classified into three categories. The first category is consumer complaints defined as complaints about fees charged by lawyers etc. Such complaints do not relate to misconduct per se. The OLSC generally resolves consumer complaints internally through mediation, and without reference to the professional associations. The second category in the classification is complaints that allege misconduct by a lawyer. Such complaints are referred to the law society or the bar association for investigation in a process that is monitored by the OLSC. A third category of complaints which involve neither consumer issues nor allegations of misconduct are investigated by OLSC staff.

By comparison the new institutional framework in the Australian Capital Territory retains many features of a self-regulatory system. The professional associations play a central role in the complaints and disciplinary process. ${ }^{38}$ Complaints against solicitors are made directly to the Council of the Law Society. In practice complaints are first considered by a subcommittee which investigates complaints and can dismiss a complaint or refer the complaint to the Law Society executive committee for consideration. The executive committe can dismiss a complaint or refer the complaint to the Council of the Law society for action. The Council is empowered to dismiss complaints, recommend mediation and to exercise summary disciplinary powers, if resolving that misconduct probably occurred the solicitor concerned is generally competent and diligent, and her or his actions were not a material breach of the misconduct standards. Alternatively if the Council considers that the misconduct standards have been materially breached it can initiate and prosecuting disciplinary proceedings against the allegedly offending solicitor. Comparable processes are followed by the Bar Association of the Australian Capital Territory.

38 Legal Profession Act 2006 (ACT), s. 394, <http://www.austlii.edu.au/ au/legis/act/consol_act/lpa2006179/s394.html>, See generally CHAPTER 4-- COMPLAINTS AND DISCIPLINE< <http://www.austlii.edu.au/au/legis/ act/consol_act/lpa2006179/>, accessed 29 October 2008. 
The exceptional case is the State of Western Australia where the professional associations are now excluded from the complaints and disciplinary process. The new legislation enacted in 2003 established a Legal Practitioners Complaints Committee consisting of seven lawyers, including the chair, and two non-lawyer community representatives. ${ }^{39}$ The Complaints Committee supervises the conduct of legal practitioners and the practice of the law and receives complaints about lawyers' conduct. The law society and the bar association are not involved in the complaints process in which the Complaints Committee exercises similar investigatory and summary disciplinary powers to those typically vested in their counterpart professional associations in other Australian jurisdictions.

In all jurisdictions the law societies and bar associations now have no power to hear complaints alleging misconduct by lawyers which cannot be determined summarily. Disciplinary proceedings in respect of conduct which the complaints process has identified as likely to demonstrate material but lesser instances of unsatisfactory professional conduct, unsatisfactory employment conduct or professional misconduct are generally undertaken before administrative tribunals.

This disciplinary jurisdiction is generally exercised by non-specialist tribunals such as the Administrative Decisions Tribunal in New South Wales often incorporating a designated legal services division. ${ }^{40}$ Tribunal members appointed to such divisions or hearing disciplinary proceedings against lawyers would normally possess special knowledge or skill in relation to the legal profession and its work. In the Australian Capital Territory disciplinary proceedings in respect of conduct which the complaints process has identified as likely to demonstrate material but lesser instances of misconduct are determined by a specialist tribunal constituted by a judge as chair, a solicitor or barrister, depending upon the complaint, and a non-lawyer selected by the Attorney-General.

Members of the professional associations are not disqualified from appointment to the administrative tribunals with jurisdiction to discipline lawyers. In fact, many tribunal members hearing disciplinary proceedings are likely to be legal practitioners or possess extensive experience of legal practice, including professional association membership. It is also likely that the law societies and the bar associations are consulted formally or informally by justice ministers and officials in the appointments process. But

${ }^{39}$ Legal Practice Act 2003 (WA), s. 162. See generally PART 12 -- Complaints and discipline.

${ }^{40}$ Administrative Decisions Tribunal Act 1997 (NSW). 
importantly membership is not the selection criteria and the interests of the associations are not directly represented in the decision making process.

The administrative jurisdictions such as the Administrative Decisions Tribunal and the Legal Practitioners Disciplinary Tribunal have extensive powers to discipline lawyers including recommending disbarment, suspending and restricting practicing certificates, imposing substantial financial penalties, ordering remedial legal education and ordering payment of costs. Disciplinary proceedings in respect of conduct which the complaints process has identified as clearly demonstrating the likelihood of significantly material or gross instances of professional misconduct are commenced before the Supreme Courts of the States and Territories and heard by judges. The courts have comparable but greater powers to discipline lawyers including the power to disbar and impose greater financial penalties.

The law societies and the bar associations obviously have no role in this. But it is important to note that in both proceedings before the administrative tribunals and the courts it is generally the law societies and the bar associations which are the prosecuting authorities.

\section{Conclusion}

For the past 20 years the legal profession and its work in Australia have been under external pressure for change - from law reformers, consumer groups and economists. In the 1990s the pressure for change came from a number of different directions at once, but for much of the time it was un-coordinated, and not all governments were prepared to act to carry the reforms into effect.

In the end the trigger for change was perhaps not so much a conviction that the legal profession should be reformed, but the desire of the national government to liberate the legal services market from the inconsistencies of the previous system of State and Territory based regulation, with the objective of achieving an efficient and nationally coherent market for legal services, to facilitate the operation of the Australian economy, including the export of legal services.

The legal profession - largely through the Law Council of Australia was a major contributor to the process of reform, and succeeded in warding off more radical proposals for change, such as those harboured by some in the TPC and the Productivity Commission. The Law Council agenda was strongly supported by the larger commercial firms, who increasingly traded nationally and internationally. But it was also supported - or at least not opposed - by many medium sized and smaller firms for whom the operation 
of the market itself and greater competition from non-lawyer services providers meant that in practice they had lees and lees to gain by resisting change.

The result is that Australia now has a new and national regulatory framework for the legal profession and its work, and it is a framework in which the law societies and the bar associations continue to play a major and important role. 


\section{References}

Australian Bureau of Statistics (ABS) (2007(a)) Cat. No. 2914.0.55.002 2006 Census of Population and Housing: Media Releases and Fact Sheets, 2006, <http://www.abs.gov.au/ausstats/abs@.nsf/7d12b0f6763c78ca ca257061001cc588/6ef598989db79931ca257306000d52b4!OpenDocu ment>, accessed 12 October 2008.

Australian Bureau of Statistics (ABS) (2007(b)) Cat. No. 2914.02006 Census of Population and Housing Fact Sheets, 2006, <http://www. abs.gov.au/AUSSTATS/abs@.nsf/Latestproducts/2914.0Main\%20Feat ures 235002006 opendocument $\&$ tabname $=$ Summary \& prodno $=2914.0$ \&issue $=2006 \&$ num $=\& v i e w=>$, accessed 12 October 2008 .

Australian Bureau of Statistics (ABS) (2008) Cat. No. 3238.0.55.001 Experimental Estimates of Aboriginal and Torres Strait Islander Australians, June 2006, <http://www.abs.gov.au/ausstats/abs@.nsf/ Latestproducts/3238.0.55.001 Main\%20Features1 Jun\%202006?opendo cument\&tabname $=$ Summary \&prodno $=3238.0 .55 .001 \&$ issue $=J u n \% 20$ $2006 \&$ num $=\&$ view $=>$, accessed 12 October 2008 .

Australian Law Reform Commission (1999) Review of the Federal Civil Justice System Discussion Paper $62<$ http://www.austlii.edu.au/ $\mathrm{au} /$ other/alrc/publications/dp/62/>, accessed 7 November 2008.

Australian Law Reform Commission (2000) Managing Justice: A review of the federal civil justice system, Report No. 89 (JS McMillan Printing Group), <http://www.austlii.edu.au/au/other/alrc/publications/reports/ 89/> accessed 7 November 2008.

Disney, J., Basten, J., Redmond, P. and Ross, S. Lawyers, 2nd ed., Sydney, Law Book Company Limited, 1986.

Law Council of Australia (2002) Model Rules of Professional Conduct.

Law Council of Australia (1996) Draft Model Rules of Professional Conduct.

Law Council of Australia (2003) Constitution of Law Council of Australia Limited ABN $85 \quad 005 \quad 260 \quad 622$ Corporations Act 2001 $<$ http://www.lawcouncil.asn.au/constitution.pdf $>$, accessed 6 November 2008.

Law Council of Australia, Policies and Guidelines - National Profession Model Rules of Professional Conduct, Date of Policy: March 2002 $<$ http://www.lawcouncil.asn.au/policy/1957352449.html>, accessed 27 October 2008. 
Memorandum and Articles of Association of the Law Society of New South Wales, <http://www.lawsociety.com.au/uploads/files/1215062555552_ 0.37991440058478004.pdf>, accessed 6 November 2008.

Professional Conduct and Practice, March $2002<\mathrm{http} / /$ www.lawcouncil. asn.au/policy/1957352449.html>, accessed 10 November 2008.

SBS (2001) World Guide, 9th ed., (Hardie Grant Publishing, South Yarra) The Law Society of New South Wales (2008) Annual Report 2008, $<$ http://www.lawsociety.com.au/uploads/filelibrary/1222738885981_0. 8662474090147137.pdf >, accessed 5 November 2008.

Victorian Bar Council (1990) The Victorian Bar Its Work and Organisation, Publications Management Pty Ltd, Melbourne $<$ http://www.vicbar.com.au/pdf/The_Independent_Bar.pdf $>$, accessed 6 November 2008.

Weisbrot, D. (1990) Australian Lawyers (Melbourne, Longman Cheshire) Wikipedia contributors (2008) "Politics of Australia", Wikipedia, The Free Encyclopedia <http://en.wikipedia.org/w/index.php?title= Politics_of_Australia\&oldid=243054110>, accessed 12 October 2008. 